\title{
WAGES, EARNINGS AND REAL EARNINGS IN TEESSIDE
}

\author{
A RE-ASSESSMENT OF THE AMELIORIST INTERPRETATION \\ OF LIVING STANDARDS IN BRITAIN,
}

1870-1914*

The following article attempts to trace the course of working-class living standards in Britain in the comparatively neglected period between 1870 and the First World War. A considerable body of historical opinion sees this period as a time of marked improvement in standards of life, an improvement based essentially on rising real wages. Studies of this period have owed a considerable debt to the pioneering work of A. L. Bowley and G. H. Wood, which produced an invaluable collection of indices for wages and real wages, upon which most general accounts of living standards in the later nineteenth century have drawn. Wood's contention that real wages, in the years roughly between 1874 and 1900 , rose by 36 per cent lies at the heart of an interpretation which sees the late-Victorian period as a time of crucial economic and social amelioration. ${ }^{1}$ The data are sufficiently comprehensive to show these improvements to be common to all occupations and to lead to the inescapable conclusion that "industrialization paid off generally in higher real wages for all groups in society in the second half of the nineteen th century". ${ }^{2}$ Steady rises in money wages, after 1870 , together with the price deflation that characterised the so-called "Great Depression" of 1874-96, allowed improvements in real incomes which "went on slowly but almost continuously except during the first decade of the twentieth century".

It has not gone unnoticed, however, that most of the income data used to support this picture of uninterrupted amelioration refer to wage rates, that is to notional rates of remuneration, and not to earnings, or actual takehome pay. Direct data on earnings (in the form, say, of company wage

\footnotetext{
* I should like to thank Dr David Taylor of Teesside Polytechnic for his comments on an earlier draft of this article.

1 G. H. Wood, "Real Wages and the Standard of Comfort Since 1850", in: Journal of the Royal Statistical Society, LXXII (1909), p. 99. This is echoed in Ph. Deane and W. A. Cole, British Economic Growth, 1688-1959. 2nd ed. (Cambridge. 1967), p. 26.

2 P. Mathias, The First Industrial Nation (London, 1969), p. 375.

${ }^{3}$ W. Ashworth, An Economic History of England, 1870-1939 (London, 1960). p. 249
} 
books) rarely survive on anything but a fragmentary basis. Furthermore, severe methodological problems attend the collection of quantifiable evidence on unemployment, short-time and overtime working. Consequently, it has not been an easy task to challenge the statistical orthodoxy developed by Bowley and Wood. Nevertheless, as long ago as 1957 Sidney Pollard indicated the dimensions that any such challenge would have to take in an article on real earnings in Sheffield which, while showing the years between 1865 and 1899 to have been ones of substantial improvements in working-class standards of life, also demonstrated that "the broad secular progress was marred by fluctuations of considerable magnitude in real incomes throughout the whole of the period from 1851 to $1914 " .4$ Anthony Slaven, drawing on an exceptionally comprehensive series of wage books, was able to show the immense cyclical fluctuations which occurred in the take-home pay of coal miners in the second half of the nineteen th century. ${ }^{5} \mathrm{G}$. J. Barnsby, taking up the theme of real earnings in the later period, has argued that "conclusions based wholly on wage and price data, even when these relate to specific local market conditions, are liable to be grossly misleading". This study also pointed to the phenomenon whereby huge cyclical fluctuations in earnings interrupted, and in the case of the Black Country restrained until the 1890's, permanent gains in real incomes and material standards of life. ${ }^{6}$ These studies, whilst scarcely amounting to a new consensus, do indicate the need to go beyond wage and real wage data into the vexed area of earnings and real earnings.

The intention here is to examine the real earnings of an entire social class in as exhaustive a manner as the evidence will allow, and consequently a single region in the North-East of England (Teesside) has been chosen for study. Teesside's economy in these years was dominated by heavy industry and by comparatively few major areas of employment. Female activity rates were low (below 20 per cent in the main town, Middlesbrough), and consequently the wages and earnings of male workers in as few as four key occupations provide a reasonable starting-point for the analysis of working-class living standards in the region. ${ }^{7}$ As will be demonstrated, the

${ }^{4}$ S. Pollard, "Real Earnings in Sheffield, 1851-1914", in: Yorkshire Bulletin of Economic and Social Research, IX (1957), pp. 54-62. See also id.. "Wages and Earnings in the Sheffield Trades, 1851-1914". ibid.. VI (1954), pp. 49-64.

5 A. Slaven, "Earnings and Productivity in the Scottish Coal-Mining Industry during the Nineteenth Century: The Dixon Enterprises", in: Studies in Scottish Business History, ed. by P. Payne (London, 1967). pp. 217-49.

${ }^{6}$ G. J. Barnsby, "The Standard of Living in the Black Country during the Nineteenth Century". in: Economic History Review. Second Series, XXIV (1971), pp. 220 and 233.

$?$ Three towns, Middlesbrough, Stockton-on-Tees and Darlington, form the basis for the study. Four main industries - iron and steel manufacture, heavy engineering, 
analysis of secular trends in terms of their individual components (cyclical, annual, and even shorter-run variations) tends to modify significantly the generally accepted picture of sustained amelioration in working-class standards of life in the late-Victorian and Edwardian period.

Figure 1 compares the course of wages and earnings of six occupational groups within Teesside's four main industries. ${ }^{8}$ It is necessary to look closely at the composition of each series in order to appreciate the often complex factors that determined both wage rates and actual earnings. This complexity is expressed most of all in the case of the iron and steel industry. Here, the bulk of the labour-force (puddlers, blast-furnace men, steel smelters, and workers in rolling and finishing) were paid in the form of piece rates according to tonnage worked, though a substantial minority (underhands and labourers, in particular) received time-rate wages. An immense variety of wage rates resulted from the large number of different grades of labour in the industry, as many as thirty branches being reported in wrought-iron manufacture alone. The relative course of these different wage rates was determined by the movement of sliding scales that tied wages, usually in the form of payment per ton of metal worked, to the selling price of manufactured iron and steel products. Basis rates, which varied in money terms from one grade of worker to another, were fixed by arbitration and corresponded to a particular selling price of pig iron, steel rails or plates. Even time-rate workers had their wages customarily altered by fluctuations in the relevant selling price, and even where sliding scales did not officially exist, or had temporarily lapsed, wage rates continued to fluctuate with prices in an extremely close manner. ${ }^{9}$

Figure 1 clearly demonstrates how average annual wages were greatly influenced by cyclical activity in the economy. There were immense year-

shipbuilding and residential construction - together accounted for some 50 per cent of total male employment.

8 A full list of the sources used to compile Figure 1 would be too lengthy to reproduce here. The main ones were, Board of Trade, Rates of Wages and Hours of Labour in Various Industries in the United Kingdom (unpublished returns kept at the Library of the Department of Employment. London). pp. 2-61. 89, 92-93, 96-109, 160-83: id., Annual Reports on Changes in Rates of Wages and Hours of Labour, 1893-1914; Returns of Wages Published between 1830 and 1886 [C. 5172] (1887): Royal Commission on Labour, Minutes of Evidence, Group A, Vol. II [C. 6795 IV], Appendix XXIII; Labour Gazette, 1893-1914.

9 See J. S. Jeans, Conciliation and Arbitration in Labour Disputes (London, 1894). pp. 77-78, and J. H. Porter, "David Dale and Conciliation in the Northern Manufactured Iron Trade. 1869-1914", in: Northern History, V (1970). pp. 157-71. 
Figure 1. Wages and earnings in Teesside, 1870-1914

Index: $1911=100$

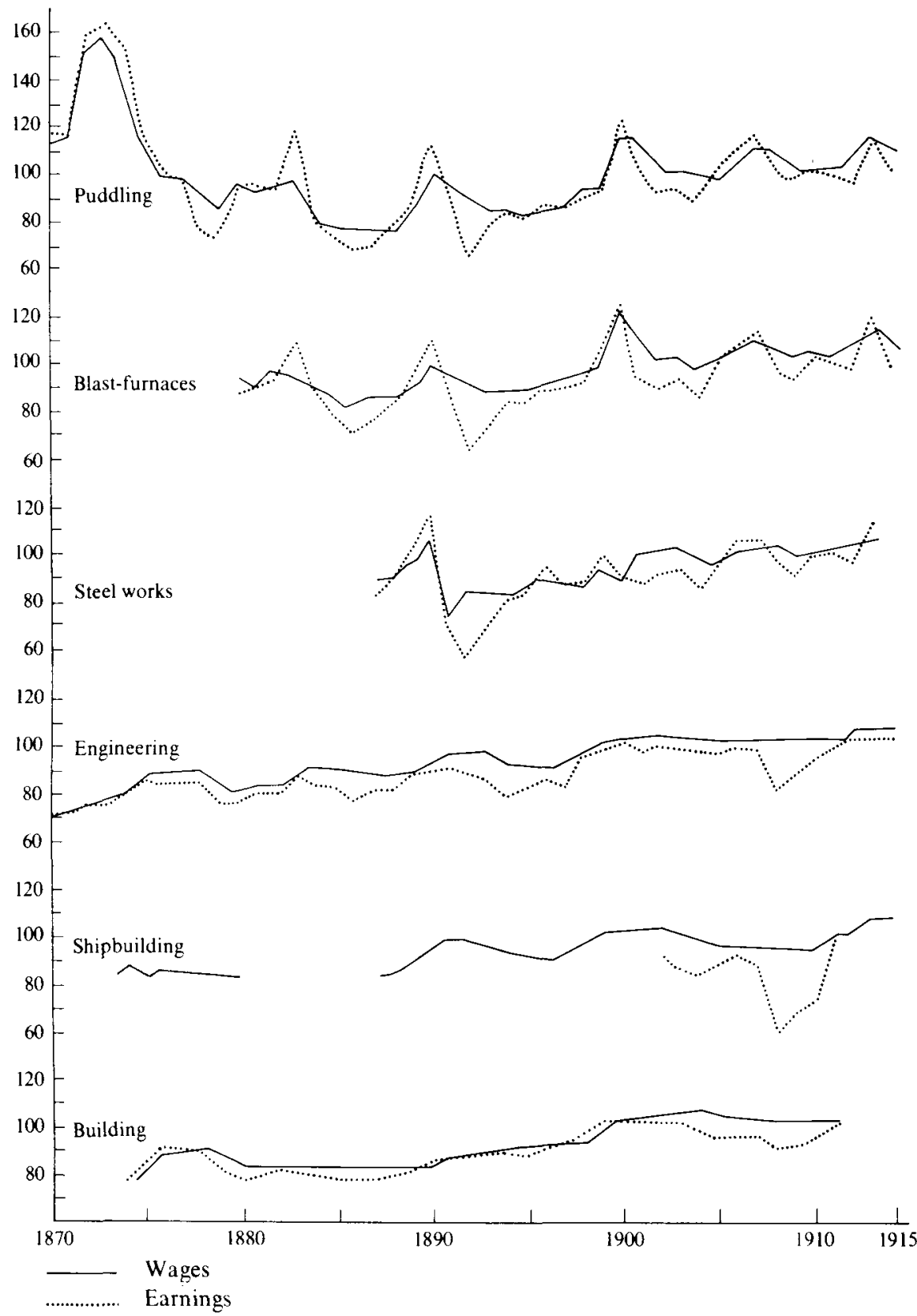


to-year variations in the wages received. Wages were high in the early 1870's, but fell during the late 'seventies and early 'eighties, levelling out up to the mid 'nineties and rising slowly thereafter. The course of wage rates in the three main branches of the industry was almost identical, the only difference lying in slightly less marked year-to-year fluctuations in the figures for steel workers as compared with workers in the other two processes. ${ }^{10}$ The unprecedented boom of 1869-74 severely disrupts the calculation of trend values. The boom was so pronounced that wages after the mid 'seventies were never able to recover their pre-1875 level. In puddling, for example, wages taken peak-to-peak (1873-1914) display a marked downward trend. If readings are taken trough-to-trough (1869-1911), however, wages are roughly equivalent in the terminal years. The question then arises of whether the boom of 1869-74 merely obscures a trend towards a secular increase in wages in (say) the period between 1860 and 1900? Lack of data both on Cleveland pig-iron prices prior to 1865 (to which in any case wage levels were not formally attached) or Cleveland puddlers' wages prior to 1869 , makes assessment rather difficult. Evidence from other regions would suggest that iron workers' wages in the 1860's were relatively high (relative, that is, to post-1875 levels) and that if the boom of 1869-74 is ignored, wage levels measured over the last four decades of the century were stagnating or even declining. ${ }^{11}$

Such is the pattern of annual changes in notional rates of pay in iron and steel. It is not an easy matter to weight the wage-rate data to allow for fluctuations in employment. There is no adequate series which depicts unemployment in the industry. The only printed series for an ironworkers' union comes from the Friendly Society of Ironfounders and the Associated Ironmoulders, and relates to a small and unrepresentative section of workers in the industry. ${ }^{12}$ Whilst a number of trade and commercial journals carry verbal statements as to the current state of trade, there are grave difficulties in translating these verbal impressions into an arithmetic

${ }^{10}$ In addition, steel workers" wages were higher during the boom of 1890 than at any other subsequent peak, whereas for puddlers the 1890 rates of pay were surpassed in 1900, 1907 and 1913.

${ }_{11} \mathrm{G}$. H. Wood's index of puddlers' wages records levels in 1866 which (apart from the boom of the early 'seventies) were not reached again until 1900. See Wood, "Real Wages". loc. cit.. p. 93. A series representing puddlers" wages in the Midlands shows wage rates between 1863 and 1870 to be at average levels above those of 1876-88 and 1892-98. See Rates of Wages and Hours of Labour, op. cit.. pp. 94-95.

12 Board of Trade. Seventeenth Abstract of Labour Statistics (1915). p. 3. The same source includes a series for workers in heavy industry which suffers from the contrasting drawback of being too broad in its application. 
index..$^{13}$ Employment data in the Labour Gazette only become available on a regional basis after 1904. Because of these difficulties employment levels on Teesside had to be estimated in an indirect fashion. Annual statistics of the number of furnaces in blast were used, when de-trended, to construct a "state of employment" index for the industry. Unfortunately, the effects of recessions on levels of employment may be understated since during periods of poor trade it was the largest and most efficient (and therefore the most capital-intensive) furnaces which were kept in operation. Nevertheless, the broad correspondence between the number of furnaces in blast on the one hand. with the number of men in employment and the total number of shifts worked on the other, is strong enough to justify the adoption of this method. ${ }^{14}$ The scope of the index is wide, embracing all processes concerned with iron and steel manufacture, and also, though less intimately, employment in finishing and rolling mills. The employment index so derived was used to weight the wage-rate data to produce the earnings' series depicted in Figure $1 .{ }^{15}$ As would be expected, the main result of this is to exaggerate still further annual fluctuations in money incomes; annual variations in earnings are seen to be far more pronounced than changes in wage rates alone. Year-to-year fluctuations were slightly greater amongst puddlers than amongst steel workers, though all workers in iron and steel, whatever their branch of trade, were evidently the recipients of chronically irregular annual earnings.

The construction of wages and earnings series for the other industries is less complicated. In the engineering industry wage-rate data are available in the form of printed series. Weekly wage rates in engineering prove to be in marked contrast to wages in the iron and steel industry. Instead of being based on the frequently fluctuating prices of finished goods they were

${ }^{13}$ In both Barnsby, "The Standard of Living in the Black Country". loc. cit.. pp. 220-22, and E. Hopkins. "Small Town Aristocrats of Labour and Their Standard of Living, 1840-1914", in: Economic History Review, Second Series, XXVIII (1975), p. 223, such a method is employed. though Hopkins was rather careful to point out its limitations. Barnsby's approach. which may have led to some exaggeration of cyclical fluctuations in levels of employment, was heavily criticised in C. P. Griffin, "The Standard of Living in the Black Country in the Nineteenth Century: A Comment". ibid.. XXVI (1973). pp. $510-13$.

14 The statistics of furnaces in blast are taken from G. T. Jones. Increasing Return (Cambridge. 1933). pp. 279-80. and R. Hunt. Mineral Statistics of the United Kingdom for 1853 and 1854 - 1881 (London. 1855-82). Changes over time in the size of, and numbers employed within. the average furnace will not distort the index in its task of expressing levels of employment or unemployment as a proportion of the total labourforce.

15 A simple arithmetic weighting was employed. i.e.

wage-rate index $x$ employment index

100 
determined by fixed time or piece rates, alterable only by the familiar bargaining process, and were, therefore, less volatile. The influence of cyclical activity was minimal. Wages in engineering rose steadily during the period with levels, in Middlesbrough in 1870, at approximately 70 per cent of their 1914 value. Unemployment returns amongst workers in the Amalgamated Society of Engineers in Middlesbrough and Stockton have been used to weight the wage-rate data to produce the earnings' series shown in Figure $1 .{ }^{16}$ This exercise reveals substantial cyclical variation in average levels of annual take-home pay. Even so, the amount of annual variation in earnings is much less than that in iron and steel. In part this is due to differences in the way the earnings' indices are constructed. Firstly, the engineering series fails to account for variations in short-time and overtime working, and is therefore less comprehensive than those for the iron and steel industry. Secondly, the ASE series used to weight the engineering wage-rate data relates to what is undoubtedly a fairly fortunate labour elite, and may underestimate levels of unemployment in the industry as a whole. Nevertheless, the main cause of the difference between the pattern of earnings in the two industries lies less in the weighting for unemployment and underemployment than in the method of wage regulation. It is at the level of wages, specifically the use or non-use of sliding scales, that the crucial distinction would appear to lie.

In shipbuilding the majority of workers received piece-rate wages, the course of which over time was closely comparable with those in heavy engineering. The wages of skilled men in iron-shipbuilding rose from an average of $28 / 4 \mathrm{~d}$ a week in 1873 to $36 / 2 \mathrm{~d}$ in $1914 .{ }^{17}$ Unemployment data for the Teesside shipbuilding industry are available only for 1902-14, and this series (embracing some five to six thousand unionised workers) shows immense annual variation in levels of employment together with exceptionally high levels during major recessions. ${ }^{18}$ The impact of boom and slump seems to have been rather more sustained in shipbuilding than in engineering. Unfortunately, the absence of unemployment data before 1902 prevents the construction of an adequate earnings' series for the period as a whole. The use of national unemployment data as a substitute is out of the question, since a comparison of local and national data for

16 Wage-rate index in year $\times$ percentage employed

Wage-rate index in base year $x$ percentage employed

17 Rates of Wages and Hours of Labour, pp. 172-82: Annual Reports on Changes. 1906-14.

18 Unemployment amongst shipbuilders reached 40.5 and 30.1 per cent in 1908 and 1909 respectively. and exceeded 10 per cent for the whole of the period 1902-10. See Labour Gazette, 1902-10. 
1902-14 shows levels of unemployment in the former to be almost double those of the latter. The data on the Edwardian period clearly suggest that the wage-rate index gives a rather false impression of steadily rising incomes; as the earnings' fragment indicates, improvements in money incomes were far more irregular and sporadic than the wage data imply.

In the construction industry wage rates rose in the early 'seventies and fell in the late 'seventies, rising again only in the 'nineties, and remaining fairly stable between 1900 and 1914. To these annual movements should be added seasonal ones; a difference of $3 /-$ a week marked skilled men's wages between summer and winter in 1870-94, increasing to $6 /-$ after the mid 'nineties. For the construction industry on Teesside there are no reliable figures on unemployment. The earnings' series depicted in Figure 1 is derived by weighting the wage-rate data by national unemployment figures. ${ }^{19}$ This may underestimate local unemployment in building, at least amongst the large minority of construction workers employed at iron and steel works. Even allowing for this, earnings in building were clearly more stable than they were in the region's metallurgical industries.

Wage data relating to the other non-metallurgical industries on Teesside are not sufficiently detailed to allow their use in building up a picture of year-to-year changes. The material that does survive for such occupations as textiles, transport, shop trades, furnishing, dockyard labour and the merchant marine suggests secular changes in wage rates very much in line with those in building or engineering, that is to say, steady increases over time in notional rates of remuneration. The impact of fluctuations in levels of employment is, however, rather more difficult to assess. On the whole, cyclical fluctuations in earnings in the non-metallurgical trades were less pronounced than in iron and steel, engineering and shipbuilding, though this was offset somewhat by higher levels of casual unemployment amongst the unskilled. The more fortunate groups (and particularly the skilled) in these lesser occupations appear to have enjoyed the relatively stable levels of annual earnings of the kind depicted in the construction workers' index. The less fortunate are likely to have been subject to the high levels of recurrent unemployment (not to mention underemployment) of the kind which distorts the index of shipbuilders' earnings after 1901. It can be safely assumed, at least, that the experience of workers outside the four main occupations is captured in at least one of the last three indices in Figure 1.

As far as wage rates considered separately are concerned, there are evident contrasts between the iron and steel industry on the one hand and

19 See Seventeenth Abstract of Labour Statistics, op. cit., p. 7. 
all other occupations on the other. The former contrasts strongly with the latter in that the wage rates traced are subject to considerable annual fluctuation, the reason lying in the use of sliding scales. In those industries in which fixed time or piece rates featured, wages rose by an average of some 30 per cent during the period, and the influence of cyclical factors on wages was subdued. By way of contrast, in iron and steel the influence of the trade cycle was pronounced, with the huge boom of the early 'seventies tending to obscure some of the rather more permanent gains made in the years after the mid 'nineties. When attention is turned to earnings, however, the effect of the trade cycle is pronounced in all occupations, though undoubtedly more so in the heavy industries. Despite inevitable anomalies in the method of construction arising from data deficiences, the calculation of the rival secular performance of the wage and earnings' in dices given in Figure $l$ indicates significant differences between the two. Furthermore, in the case of the engineering, shipbuilding and building industries the failure to incorporate weights for short-time working in the earnings' indices undoubtedly leads to some understating of the fluctuations which actually occurred. Evidence of the kind assembled for Teesside suggests strongly that data on wage rates are but poor guides to levels of take-home pay and to annual variations in average levels of earnings.

It is possible to take the comparison of wages and earnings beyond the consideration of purely annual, cyclical and secular trends. Analysis of extremely short-run variations in wages and earnings also reveals significant contrasts between the levels of income predicted by wage rates and those secured in practice. Surviving wage books for Teesside, whilst unsuited to the analysis of long-term trends, may be used to illustrate this point. To quote a single example, the average weekly earnings of some 400 steel workers in the period from September 1913 to December 1914 were found to vary from $18 /$ - to $37 /$ - a week, though most weeks fell within the range of $29 /-$ to $37 /-$. As for the experience of in dividual workers, it was quite common for the earnings of first-hand smelters to vary by as much as ten or twenty shillings from one week to the next. Similarly, examples of the take-home pay of fitters and labourers demonstrate how the weekly earnings of time-rate employees varied due to immense weekly fluctuations in the number of hours worked. ${ }^{20}$ Variations of this kind occurred at

20 Cargo Fleet Iron Company, Steel Works' Wages Books, 1912-14. British Steel Northern Regional Records Centre. Middlesbrough. I am indebted to the Corporation for permission to consult these records. 
a level rarely captured, and certainly never fully expressed, by annual data on changes in levels of employment. ${ }^{21}$ It is evident that the uncertainty surrounding levels of take-home pay was as true of the short term as it was of the long (of the week-to-week as of the year-to-year), and that in terms of the experience of workers and their families these shorter-run fluctuations may have been of greater concern. Short-term changes in income, of the magnitude suggested by the surviving wage books, compelled the extensive use of savings, insurance and adjustments to weekly budgets, and necessitated a degree of planning ahead and provision for the future that may not have been entirely easy for working-class families of the period.

Similarly, the study of annual, cyclical and secular trends in wages and earnings throws little light on another crucial phenomenon, namely the true extent of income differentials within the working class. In all industries the basis for extensive differentials in take-home pay was built into the wage structure, and these differentials were especially acute in the iron and steel industry with its scores of different labour processes, each with its own characteristic rate of remuneration. But marked wage differentials existed in other industries too. In engineering, for example, at the end of the period, the highest-paid skilled workers (patternmakers) received about 15 per cent $(5 /-)$ more than the lowest paid (planers). Amongst boilermakers differentials were even more marked, with angle-iron smiths receiving about 25 per cent $(9-10 /-)$ more than holders-up. ${ }^{22}$ The wages of the unskilled, however, were no more than two-thirds of the skilled, rising from about $16 /$ - in 1870 to about $20-22 /$ - a week in $1905 .^{23}$ In shipbuilding, workers such as angle-iron smiths and platers received 25 per cent $(7 /-)$ more than holders-up in the 'eighties, a margin retained throughout the period. ${ }^{24}$ Although skilled men in shipbuilding received up to $35 /$ - a week by the end of the period, many general labourers in the industry, as late as

21 In the present context, documentary evidence is confined to iron and steel, though there is every reason for assuming short-run variations to be common in all metallurgical industries. In non-capital-sector industries these variations will have been less intense. However. seasonal variations in earnings in the building industry were of the order of some 13 per cent on Teesside in this period. whilst in other regions the difference between summer and winter earnings was evidently greater. See Annual Reports of the Operative Bricklayers Society, 1874-1914. The Modern Records Centre. University of Warwick, Coventry, and R. Q. Gray, The Labour Aristocracy in Victorian Edinburgh (Oxford, 1976), p. 51.

22 Rates of Wages and Hours of Labour, pp. 146-49; Annual Reports on Changes, 1906-14.

23 Board of Trade. Enquiry into Working-class Rents, Housing and Retail Prices (1908), Town Reports [Cd 3864], pp. 314, 436.

${ }^{24}$ Rates of Wages and Hours of Labour, pp. 168-72; Annual Reports on Changes, 1906-14. 
1906, received little more than a pound a week, and a fifth of the men employed in shipyards in the North-East received weekly earnings of less than $25 /-.^{25}$ Only in the building industry did differentials between different grades of skilled men narrow significantly during the period. Whereas in 1874 masons received 25 per cent more than carpenters and joiners, wages by 1905 were more uniform; masons, bricklayers and plasterers received $91 / 2 \mathrm{~d}$ an hour, carpenters and joiners $91 / 4 \mathrm{~d}$. By way of contrast, however, differentials between skilled and unskilled diminished little during the period, the latter receiving about two-thirds of the skilled man's wage. ${ }^{26}$

Inevitably, differentials in actual earnings were even greater than the wage structure would suggest. In iron and steel, for example, earnings varied not only between different grades of labour in the same works, but even between the same grades of labour in different works or different parts of the same works. Such factors as experience and responsibility played their part in these differences, but the key reason lay in the technical efficiency of the plant in question, operation of the most advanced (and therefore, under piece-rate sytems, most remunerative) process being a valuable prize which generally accompanied seniority of service. Thus there was a tendency for the older workers (provided they remained fit) to command the highest piece-rate earnings. ${ }^{27}$ The true extent of earnings' differentials in the Teesside iron and steel industry is indicated by the Board of Trade's "Earnings and Hours" inquiry of September 1906. This revealed not only the immense variety of earnings received (from $15 /-$ to $100 /$ - a week), but also the marked disparity between the earnings of piece-rate and time-rate workers, those of the former (generally more skilled) being consistently higher. ${ }^{28}$ Income differentials, albeit less marked, were typical of most industries, and since the unskilled tended to suffer more than the skilled from unemployment and underemployment, these were rather more marked than the wage structure alone would suggest. At the same time, the differences in earnings which can be traced between skilled and unskilled represent merely two extremities of a wide spectrum of differentiated income, both within and between industries. This complex pattern of differentiated income was inevitably reflected in wide variations in life styles and standards of life.

${ }^{25}$ D. Dougan, A History of North East Shipbuilding (London. 1968). p. 128.

26 Rates of Wages and Hours of Labour, pp. 2-48; F. W. Lawrence, Local Variations in Wages (London, 1899), pp. 111-13.

27 Jeans, Conciliation and Arbitration, op. cit.. p. 99; Royal Commission on Labour, Minutes of Evidence, Group A, Vol. II, qq. 15154-482.

28 Board of Trade, Report on Earnings and Hours of Labour in the Metallurgical Industries, Engineering and Shipbuilding for 1906 [Cd 58 [4]. 


\section{III}

The plethora of local evidence on wages and earnings is not reflected in the data available on diet and consumption. The only strictly local evidence comes from Lady Florence Bell's house-to-house survey of iron workers' families in Middlesbrough, the results of which were published in 1907. In all Lady Bell gives eleven weekly budgets which reveal consumption to have been characterised by extremely limited diets with little variety. A family of mother, father and twelve-year-old girl, with a weekly income of about a pound, based their diet on meat, flour, bread meal, butter, bacon, sugar, tea, yeast and a little milk; the only vegetables eaten were potatoes and onions. Nor do the other budgets, which relate to families with rather higher weekly incomes, suggest that a large number of new foodstuffs had come to be important elements of working-class diets. ${ }^{29}$

Clearly, however, budgetary data of this nature are insufficiently detailed to justify their use as a basis for calculating consumption and the cost of living. As a result, it is necessary to turn away from evidence relating purely to Teesside. A comprehensive break-down of working-class diets in Northern England for the period 1902-13 is readily available and can be extended, with little difficulty, to the longer period beginning in $1870 .^{30}$ As a result, it is possible to allocate the consumption of eleven principal foods $^{31}$ in a way which represents the average weekly consumption of families of varying incomes. ${ }^{32}$ Since diets in the region appear to have been fairly monotonous, even in the Edwardian period, it can be reasonably expected that these eleven foods would account for the bulk of workingclass expenditure on necessities. The evidence from local market reports

29 F. Bell, At the Works: A Study of a Manufacturing Town [Middlesbrough] (London, 1907), pp. 56-65, 72-75. The fragmentary evidence given by Lady Bell contrasts strongly with the varied diets customary in another iron-manufacturing district. See E. Roberts, "Working-Class Standards of Living in Barrow and Lancaster, 1890-1914" in: Economic History Review, Second Series, XXX (1977), pp. 306-21.

${ }^{30}$ See D. J. Oddy, "The Working-Class Diet, 1886-1914" (unpublished Ph.D. thesis, University of London. 1970), pp. 217,236 ; id., "Working-Class Diets in Late Nineteenth Century Britain", in: Economic History Review. Second Series, XXIII (1970), pp. 314-23. The years between 1886 and 1914 exhibit a remarkable uniformity in food consumption. Whilst diets were enriched in the late 'seventies and early 'eighties by the addition of certain new foods, they remained relatively unchanged thereafter until the war. The main difference between the Victorian and Edwardian diets would appear to lie in a slightly higher consumption of protein and fats in the later priod. See Oddy, "The Working-Class Diet", pp. 258, 336. Any distortion which takes place as a result of the use of Edwardian diets as the norm will tend to occur largely in the early 'seventies.

31 Bread, potatoes, sugar, oatmeal, butter, lard, beef, mutton, bacon, milk and tea.

32 Five major income groups are used, representing weekly incomes of $25 /$ - and under. $25-30 /-.30-35 /-.35-40 /-$ and $40 /-$ and over. 
indicates that, whilst a large number of other foods were available during the year, their price and extreme seasonality (especially of fruit and vegetables) kept them out of the reach of working-class pockets for all but a very brief period of the year. Furthermore, a study of urban geography (in the case of Middlesbrough at least) indicates that allotments were not numerous and that, therefore, "free" sources of food were fairly atypical. Consumption of alcohol and tobacco has not been included in the estimates, though both were undoubtedly important, and the former a relatively expensive item, in a number of workers' diets. Nevertheless, expenditure on alcohol varied greatly from one family to another, and for this reason it was thought preferable to exclude it from the budgetary survey. It is assumed, therefore, that drink was either a "luxury" item, the costs of which were met by surplus earnings, or an item of expenditure which caused the budgets of some families to deviate from the "rational norm".

This ascertained average pattern of consumption makes possible the construction of a cost-of-living index. Here again, however, there are data problems, specifically the partial nature of retail price evidence. The only relevant retail price data for Teesside are limited to flour, butter, eggs, certain meats, onions and potatoes. Contract prices, suitably adjusted, ${ }^{33}$ have been used to supplement these, and the average annual prices of the principal foodstuffs for 1870-1914 have been calculated. In order to estimate household consumption an allowance for rent and for items such as fuel, clothing, insurance and sundries (cleaning materials, utensils, hardware, etc.) has been added. ${ }^{34}$ From this, cost-of-living indices for the five income groups were calculated for the period 1870-1914, the mean of which is depicted in Figure 2. 1870-78 were the years of highest prices on Teesside. Between 1878 and 1883 the cost of living fluctuated rapidly,

${ }^{33}$ Naturally, contract prices understate retail ones by a considerable amount. The solution adopted here was to compare the value of retail and contract prices for those items for which both types of data were available. Contract prices were found to understate retail ones by some 20 per cent, a ratio fairly constant throughout the period. Wherever contract prices have been used, therefore, they have been adjusted in order to render them comparable with the retail data.

34 Rents in 1910 in Middlesbrough were 3/6. 4/-,5/- and 6/6 for two-, three-, four-, and five-roomed houses respectively. These rental levels were allocated amongst the five different income groups according to income. Then, on the basis of the index of house rents constructed by Singer (H. W. Singer. "An Index of Urban Land Rents and House Rents in England and Wales, 1845-1913", in: Econometrica, IX (1941), p. 230), rents for the whole period were calculated. The consumption and costs of the remaining items were taken from budgets in F. Bell, At the Works, op. cit., pp. 56-60, and The Economic Club, Family Budgets, Being the Expenditure of Twenty-eight British Households, 1891-94 (London, 1896). 
Figure 2. The cost of living in Teesside, 1870-1914

Index: $1911=100$

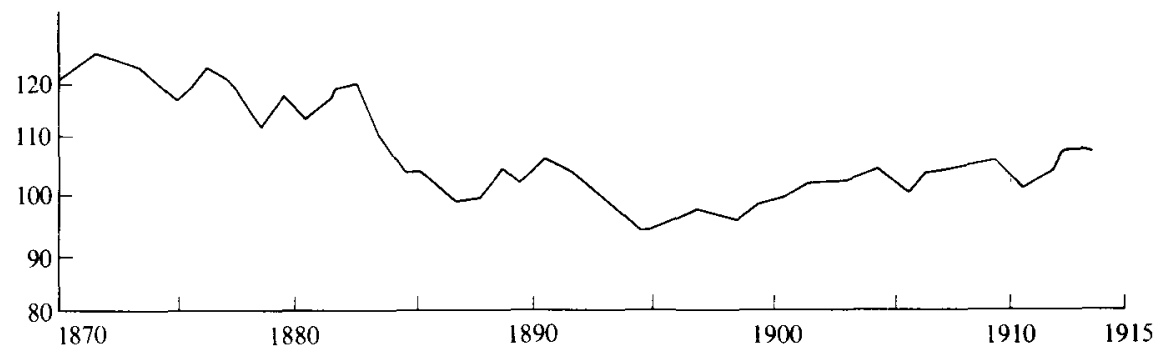

The pattern of consumption is based on Oddy, "The Working-Class Diet" (see note 30) p. 236. although certain alterations were made to Oddy's figures in order to make them suitable for the construction of the relevant price series. The main changes involve the adjustment of consumption estimates in order restore the volume of foods purchased to their retail, or pre-preparation, levels. An allowance for rents and sundries has been added. Food prices are taken from Darlington and Stockton Times, 1870-1907. Stockton-on-Tees Herald, 1908-14, Darlington Board of Guardians, Minutes, 1870-1903, and Stockton-on-Tees Board of Guardians. Minutes, 1904-13.

though even the lowest values of these years were high relative to price levels thereafter. A substantial fall in the cost of living began in about 1883 and living costs remained steadily at comparatively low levels between 1884 and 1899 (apart from a slight rise in 1889-93). Although they began to rise thereafter, the increase was gradual and undramatic. The cost of living in 1914 was approximately 90 per cent of its 1870 value, though this somewhat bald statement tends to underestimate the overall fall during the forty-five years as a whole. From peak to trough (1872-95) the cost of living fell by 24 per cent. ${ }^{35}$ This fall in the price of necessities affected the various income groups equally, with only one significant caveat. Since subsistence items of consumption (notably bread and potatoes) fluctuated more acutely in price than other items, the poorer groups suffered most (relatively speaking) from higher living costs and gained most from periods of deflation.

\section{IV}

The earnings' series in Figure 1 have been deflated by the relevant costof-living index to produce the real earnings' series depicted in Figure 3.

35 Results concurring closely with Wood's index of rent and commodities for 1870-1902, "Real Wages", pp. 102-03, and the Ministry of Labour's index of retail food prices for 1892-1914, given in B. R. Mitchell and Ph. Deane, Abstract of British Historical Statistics (Cambridge, 1962), p. 478. (Apart from the fact that in the case of the latter the steep rise in prices after 1906 is not emulated on Teesside.) 
Figure 3. Real earnings in Teesside, 1870-1914 Index: $1911=100$

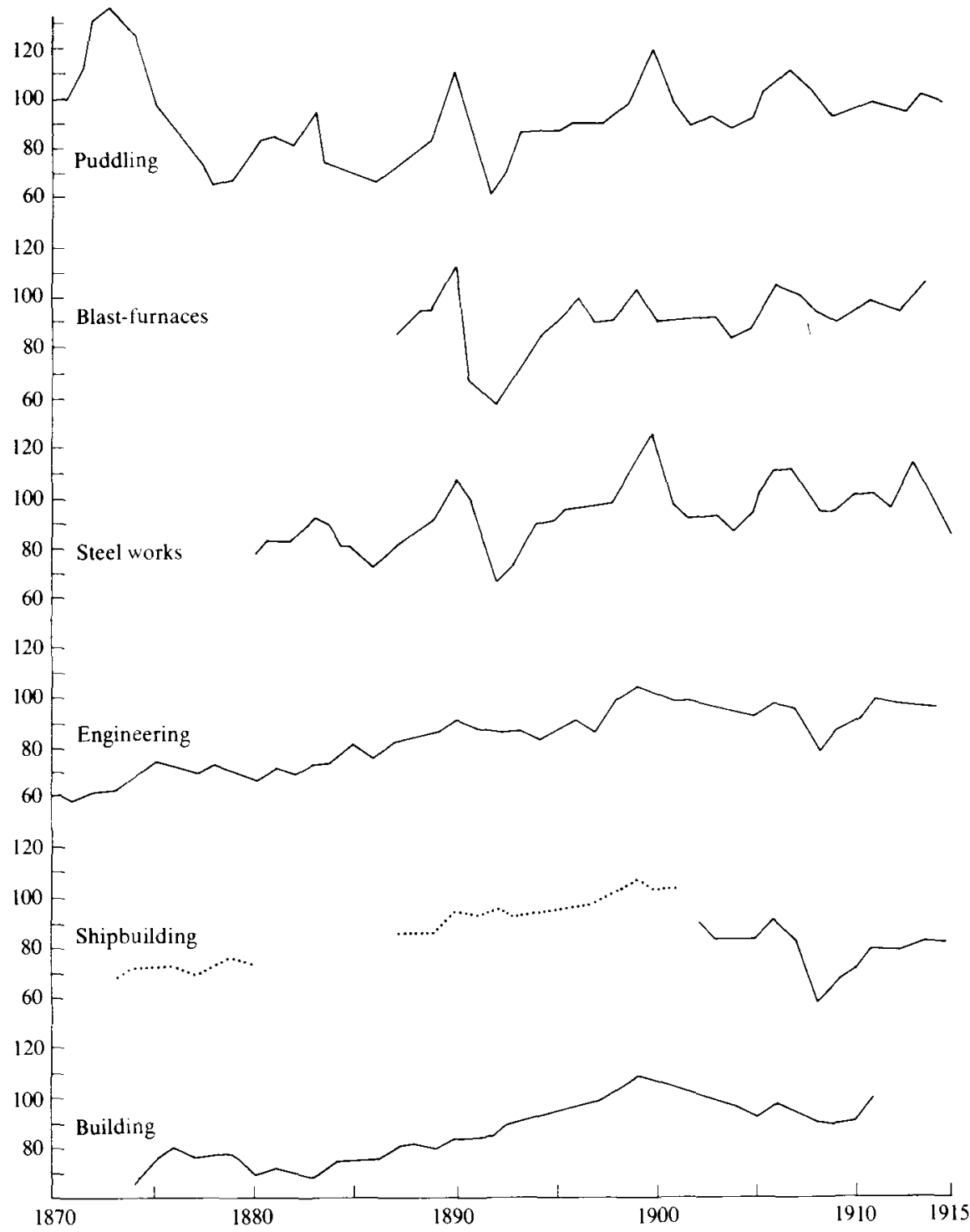

Real wages in $1911=100$ 
Real earnings in the iron and steel industry were characterised by wide variations from one year to the next. The index of puddlers' real earnings (which for the 'seventies may be taken as typical of the iron industry as a whole) varied from a peak of 135.7 in 1873 to a trough of 63.3 in 1892 (where $1911=100$ ). Because of these immense annual variations the trend is not immediately visible. The mean of the puddlers' index for the years 1870-79 stands at 99.7, whilst that for 1900-09 is only marginally higher at 100.6. Real earnings amongst blast-furnace men and steel workers were similarly subject to immense annual variation. Since all workers in the industry were paid in the form of piece rates tied, formally or informally, to sliding scales, the amount of variation depicted must be deemed typical of the industry as a whole, of skilled and unskilled alike. Real earnings were high in 1870-75, but fell rapidly in the second half of the 'seventies, and (apart from the boom years of 1883 and 1890) these low levels were maintained until the mid 'nineties. Thereafter, a secular rise in levels of real incomes occurred, albeit one punctuated severely by immense cyclical fluctuations, to the eve of the First World War. The period of lowest real earnings corresponded closely to the "Great Depression" of 1874-96. The fact that food prices fell considerably during at least a part of this period was insufficient compensation for reductions in earnings. Gains in real earnings, for workers in iron and steel, came not in the last quarter of the century, when food prices fell, but during the early 'seventies and the first decade of the twentieth century when wages and earnings rose.

Figure 3 also shows annual changes in real earnings amongst workers in the engineering, shipbuilding and building industries. The data are in marked contrast to those for iron and steel. Cyclical fluctuations, though significant particularly in engineering and shipbuilding, were less pronounced and secular growth over the period as a whole is more clearly visible. Amongst engineering workers with weekly wages of 30-35/-, the mean index value for 1870-79 stands at 66.1, rising to 93.9 for 1900-09. Unlike the developments in the iron and steel industry, real earnings continued to rise during the "Great Depression", and here the existence of steady wage rates, as opposed to the wildly fluctuating ones that operated in iron and steel, allowed the full secular impact of falling retail prices to show through. Real earnings fell slightly, however, when food prices began to rise again after 1900 . The examination of real earnings in shipbuilding is handicapped by the lack of unemployment data for 1870-1901. Yet even given the fact that the index for these years is artificially inflated, real earnings over the period as a whole are still seen to rise. It remains true, however, that if one assumed the cyclical unemployment of 1902-14 to be reflected (even at a reduced level) in the pre-1900 period, the pattern in 
shipbuilding would be one of slow rises in real incomes punctuated frequently by high unemployment and inevitably depressed earnings. By way of contrast, the pattern in the construction industry was for a more sustained growth in real earnings to 1900 , with a fall in the Edwardian period as a result of the increase in the cost of living.

For most sections of the working class, with the important exception of those in iron and steel manufacture, the period in question saw substantial increases in real income, and this conclusion concurs with the generally accepted picture of economic and social amelioration in late-Victorian and Edwardian Britain. Yet the improvements in real earnings which formed the basis for this amelioration may not have been as regular or as sustained as many writers have assumed. Those commentators who have used realwage data to speak of annual percentage rises in material standards of life tend to misrepresent the facts. Gains in real earnings came generally in leaps and bounds, and many of them were made only to be relinquished shortly afterwards. In terms of the lived experience of working people and their families the effect of the trade cycle was to produce rapid fluctuations, both short-term and long-term, in earnings and real earnings. ${ }^{36}$ Although historians find it convenient to analyse real earnings in terms of the net outcome of a number of individual fluctuations, workers and their families would have experienced the effects of these fluctuations in their more immediate aspect. A hypothetical individual whose working life began in 1870 and ended in 1914 might conceivably look back over the period and speak of long-term improvements, but his actual experience through the years would have been one of constant change, of alternate progress and regress. Similarly, a growth in real earnings of one per cent per annum might be quite different in terms of an individual's actual experience to a growth of ten per cent over a decade. Fluctuating incomes of the kind typical in Teesside were rather less satisfactory than stable ones, even if the average of the two trends could be said to have been the same.

The present examination of living standards in the Teesside region has three broad implications. Firstly, the purchasing power of working-class incomes depended not simply on the relative movements of wages and prices. A number of other factors, and in particular the role played by sliding scales and the relative impact of unemployment, short-time and overtime working, tended to complicate the relationship between wage

36 To this must be added the further uncertainty stemming from fluctuations in the life cycle. 
rates and living costs. The importance of these qualifying factors has frequently been underestimated. The influence of sliding scales can be shown to be crucial in regions in which the coal-mining or metallurgical industries can be said to have been important constituents of the local economy. The impact of fluctuations in the volume of employment was crucial everywhere, though especially so in regions with heavy industries geared to the production of goods for the capital sector. In this context the distinction between real wages and real earnings is clearly a crucial one, and has implications not only for the later nineteenth century but also for the earlier, more passionately debated, period between 1760 and 1840 . Secondly, the relative importance of the various factors of which real earnings were composed varied not only from one occupation to the next, but also in some cases between different grades of labour in the same occupation. Only by a thorough examination of the differential impact of a wide variety of factors can the true complexity of working-class incomes be grasped. Finally, in terms of changes over time, real earnings deserve to be studied at at least four different and contrasting levels: the short-term (weekly or monthly), the annual, the cyclical, and the secular. Each may be said to have had a particular pattern and a particular impact on the individual experience of workers and their families. Attention to these three points should certainly help to enhance the accuracy with which statistical abstractions may be employed to depict the true nature of working-class incomes and material standards of life. 